\title{
YOUNG, OLD, AND WEATHERED CARBON-PART 1: USING RADIOCARBON AND STABLE ISOTOPES TO IDENTIFY CARBON SOURCES IN AN ALKALINE, HUMIC LAKE
}

\begin{abstract}
Evelyn M Keaveney ${ }^{1,2} \bullet$ Paula J Reimer ${ }^{1} \bullet$ Robert H Foy $^{3,4}$
ABSTRACT. This article presents a case study of Lower Lough Erne, a humic, alkaline lake in northwest Ireland, and uses the radiocarbon method to determine the source and age of carbon to establish whether terrestrial carbon is utilized by heterotrophic organisms or buried in sediment. Stepped combustion was used to estimate the degree of the burial of terrestrial carbon in surface sediment. $\Delta^{14} \mathrm{C}, \delta^{13} \mathrm{C}$, and $\delta^{15} \mathrm{~N}$ values were measured for phytoplankton, dissolved inorganic carbon (DIC), dissolved organic carbon (DOC), and particulate organic carbon (POC). $\Delta^{14} \mathrm{C}$ values were used to indicate the presence of different sources of carbon, including bedrock-derived inorganic carbon, "modern," "recent," "subsurface," and "subfossil" terrestrial carbon in the lake. The use of ${ }^{14} \mathrm{C}$ in conjunction with novel methods (e.g. stepped combustion) allows the determination of the pathway of terrestrial carbon in the system, which has implications for regional and global carbon cycling.
\end{abstract}

\section{INTRODUCTION}

The structure and function of aquatic ecosystems are strongly influenced by carbon imported from terrestrial catchments. With nutrient inputs, the relative composition and character of carbon entering lakes is a significant driver of energy mobilization and utilization by lake heterotrophs. An estimated 2.9 Pg of carbon is exported annually from terrestrial catchments to freshwater (Tranvik et al. 2009; Butman and Raymond 2011). Transfer of terrestrial carbon (e.g. plant matter, soil, peat) to higher trophic levels can be considerable in lakes with even moderately high organic loading. Increased precipitation, temperature, and consequently greater mobility of DOC lead to higher export of catchment terrestrial carbon (Vuorenmaa et al. 2006).

Elevated autochthonous photosynthetic production can lead to higher burial rates in lake sediment (Heathcote and Downing 2012). Significant loading of terrestrial carbon (TC) metabolized in the food web leads to increased $\mathrm{pCO}_{2}$ values and consequently elevated $\mathrm{CO}_{2}$ flux to the atmosphere (Gupta et al. 2008), while a lengthened photoperiod can increase photomineralization of DOC and elevate bacterial production (Kritzberg et al. 2006; Koehler et al. 2014). Diagenesis of carbon can lead to decreased nutrient quality, determining the likelihood of metabolization in the food web or alternatively burial in sediment.

Catchment changes (soil erosion, peat cutting, dredging, etc.) and/or extreme flood events may lead to the export of terrestrial carbon, which may supplement or supplant freshwater primary production (autochthonous). Terrestrial carbon can be derived from material of different ages. Modern terrestrial carbon is derived from photosynthetic material, contemporary with the modern atmosphere. Recent carbon can be derived from surface soil composed of recently deposited plant material that has undergone minimal decay. Subsurface or subfossil carbon previously sequestered in soil/peat stocks can be decades to centuries old (Trumbore 2000; Douglas et al. 2014).

The source of carbon in a lake also determines its biochemical composition and nutrient quality and likelihood of metabolization in the food web. Autochthonous carbon and labile terrestrial carbon released from soil minerals are relatively high-nutrient food sources and are likely to enter the food web (Caraco et al. 2010; Ishikawa et al. 2013, 2014). Older detrital TC is lower quality and so is less likely to be a nutrient resource for lake biota, precluding its selection by heterotrophic organisms (Butman et al. 2007, 2012; Ågren et al. 2008; Roiha et al. 2012).

1. ${ }^{14}$ CHRONO Centre, School of Geography, Archaeology and Palaeoecology, Queen's University Belfast BT71NN, UK.

2. Corresponding author. Email: e.keaveney@qub.ac.uk.

3. Agri-Food and Biosciences Institute, Newforge Lane, Belfast BT95PX, UK.

4. School of Biological Sciences, Queen's University Belfast BT71NN, UK.

Proceedings of the 1st International Radiocarbon in the Environment Conference 18-22 August 2014, Queen's University Belfast, Belfast, Northern Ireland, UK Edited by Evelyn Keaveney and Paula Reimer 
In light of the global increase of terrestrial loading to freshwater (Lapierre et al. 2013), the goal of this study was to determine the source and pathway of TC in Lower Lough Erne (Northern Ireland) with complex carbon dynamics, in order to address the following questions:

- What comprises the carbon pools available to autotrophic and heterotrophic organisms (modern, recent, bomb, or subfossil terrestrial organic, geological inorganic, or atmospheric carbon) in Lower Lough Erne?

- Is terrestrial carbon utilized by heterotrophic organisms [becoming a potential source of greenhouse gases (GHGs)] or is it buried in the lake sediment?

\section{BACKGROUND}

As the pathways of carbon in a freshwater lake are intrinsically linked with biotic processes, the carbon sources utilized by autotrophs and heterotrophs need to be determined.

\section{Autotrophic Production}

It has been demonstrated that $\delta^{13} \mathrm{C}$ values of aquatic photosynthetic plants and plankton utilizing inorganic carbon in lakes are variable due to differences in carbon availability and kinetic fractionation (Farquhar et al. 1989; McConnaughey et al. 1997). Inorganic carbon is derived from the atmosphere, whereas microbial decay of terrestrial vegetation and geological weathering each represent a stable isotope and radiocarbon end member (Broecker and Walton 1959; France 1995; Carpenter et al. 2005; Cole et al. 2006; Nara et al. 2010; Zigah et al. 2011).

Stable carbon isotope analyses utilize models of photosynthetic fractionation to identify an isotopic baseline signal for phytoplankton (Karlsson et al. 2003; Pace et al. 2004). There is debate on the accuracy of these methods as it is difficult to determine whether phytoplankton utilize dissolved $\mathrm{CO}_{2}$ or bicarbonate (Smyntek et al. 2012). There are also difficulties with sample size and isolation of phytoplankton, as well as considerable variation in phytoplankton $\delta^{13} \mathrm{C}$ values depending on carbon source (Carpenter et al. 2005; Bade et al. 2006; Smyntek et al. 2012). Isotopic food web studies require separation between different sources, but baseline autotrophic $\delta^{13} \mathrm{C}$ signals are sufficiently variable to overlap with other end members (Ishikawa et al. 2013).

\section{Heterotrophic Metabolization of Organic Carbon}

Debate remains as to processes by which dissolved and particulate organic carbon (DOC and POC, respectively) are utilized by lake heterotrophs in addition to the fraction of each consumed (Bartels et al. 2012; de Kluijver et al. 2012; Wilkinson et al. 2013). The biochemical composition and resulting nutrient value (biochemical quality) of DOC or POC governs selection as a food source, yet stable isotope end members are often insufficiently distinct to distinguish them as carbon sources to aquatic consumers.

Many studies suggest the biochemical quality of the organic input is an important factor governing its fate in lakes, and this may explain why in some lakes DOC is the predominant terrestrial carbon source utilized by zooplankton (Taipale et al. 2007, 2008; McCallister and del Giorgio 2008; Zigah et al. 2011; de Kluijver et al. 2012). Seasonality is an inherent characteristic of temperate lakes with alternation between high summer to low winter autochthonous production according to changes in light and temperature, which affect the magnitude and temporal delivery of nutrients (Grey et al. 2001; Kritzberg et al. 2006; Neff et al. 2006; Rautio et al. 2011). Carbon fixed by phytoplankton and algae is bio-energetically rich compared to the bulk of the terrestrial organic input to lakes due to prior diagenesis. Accordingly, lake heterotrophs tend to optimize their feeding to exploit such 
dietary sources. Thus, the carbon source maintaining but also producing biomass can shift considerably with the seasonal availability of resources (Maguire and Grey 2006; Rautio and Vincent 2007; Taipale et al. 2008; Rautio et al. 2011).

\section{Using ${ }^{14} \mathrm{C}$ to Determine Carbon Source}

Natural-abundance ${ }^{14} \mathrm{C}$ analysis can be used to clarify lake carbon dynamics that cannot be explained using stable isotope analysis alone. $\Delta^{14} \mathrm{C}$ (see Methods for derivation) of freshwater carbon is governed by its source. Normalization of ${ }^{14} \mathrm{C}$ values (see Methods) negates the issue of kinetic fractionation, allowing for the isolation of a baseline isotopic signature and accurate separation of individual carbon sources. Low natural abundance of the ${ }^{14} \mathrm{C}$ atom allows for a more sensitive approach to source partitioning than stable carbon isotope analysis. $\Delta{ }^{14} \mathrm{C}$ values distinguish between carbon sources since relatively minor isotopic changes are amplified due to the low ${ }^{14} \mathrm{C}$ abundance in a sample.

For the purposes of this study, the following five terms were utilized to describe the source and age of carbon in the lake:

1. Modern terrestrial carbon is derived from photosynthetic material contemporary to the modern atmosphere.

2. Recent terrestrial dissolved and particulate organic carbon can be exported from surface soil and may be derived from recently deposited plant material that has undergone minor decomposition.

3. Subsurface terrestrial soil stocks may incorporate ${ }^{14} \mathrm{C}$ that has a distinct bomb signal, enriched relative to the modern atmosphere due to nuclear testing in the 1950s and 1960s and resulting in positive $\Delta^{14} \mathrm{C}$ values (Reimer et al. 2004). However, due to soil carbon cycling and turnover, atmospheric carbon with enriched $\Delta^{14} \mathrm{C}$ can take decades to reach subsurface soil stocks (Trumbore et al. 1989; Polsenaere et al. 2013). Carbon from subsurface soil or peat may therefore have a positive $\Delta^{14} \mathrm{C}$ value, enriched relative to the modern atmosphere.

4. Subfossil carbon originates from terrestrial carbon stored in soil/peat stocks that can be considerably ${ }^{14} \mathrm{C}$ depleted depending on the age of stored carbon (MacDonald et al. 1991; Raymond et al. 2004; Caraco et al. 2010).

5. Autochthonous carbon is generated from primary production, which utilizes dissolved inorganic carbon that is partially derived from the weathering (via atmospheric $\mathrm{CO}_{2}$ or soil carbon) of carbonaceous bedrock with no ${ }^{14} \mathrm{C}$ content $\left({ }^{14} \mathrm{C}\right.$-dead) leading to ${ }^{14} \mathrm{C}$-depleted DIC values (Deevey et al. 1954; Broecker and Orr 1958; Broecker and Walton 1959). Measurements from fish and water samples from a number of lakes in Ireland and Britain in 2007 indicated that a hardwater offset may be estimated from lake carbonate alkalinity $\left(R^{2}=0.66, p<0.01\right.$, Keaveney and Reimer 2012) with the caveat that large variations can be present due to fluctuating terrestrial inputs, particularly in oligotrophic (nutrient-poor) lakes. ${ }^{14} \mathrm{C}$ and stable isotope measurements of inorganic and organic carbon pools (DIC, DOC, and POC), photoautotrophs, and heterotrophs can therefore provide a means to assess the importance of terrestrial carbon cycling in aquatic primary production and to resolve the following hypotheses:

- Modern terrestrial and autochthonous carbon is preferentially metabolized by lake heterotrophs, leading to $\mathrm{CO}_{2}$ saturation and probable flux to atmosphere.

- Subfossil terrestrial carbon is not consumed by lake heteretrophs and is buried in sediment. 


\section{METHODS}

\section{Study Site}

We selected Lough Erne, Northern Ireland (Figure 1), primarily because in a previous study (Keaveney and Reimer 2012), it did not follow the trend of increasing ${ }^{14} \mathrm{C}$ offsets from the atmosphere with increased carbonate alkalinity. A great deal of research on past environmental records has also been carried out on the lake (Gibson et al. 1980, 2003, 2005; Battarbee 1986, 1984; Foy et al. 1993; Maguire and Gibson 2005) and the lake is regularly monitored by the Agricultural Food and Biosciences Institute (AFBI) of Northern Ireland, providing water chemistry data as part of the UK Environmental Change Network (ECN).

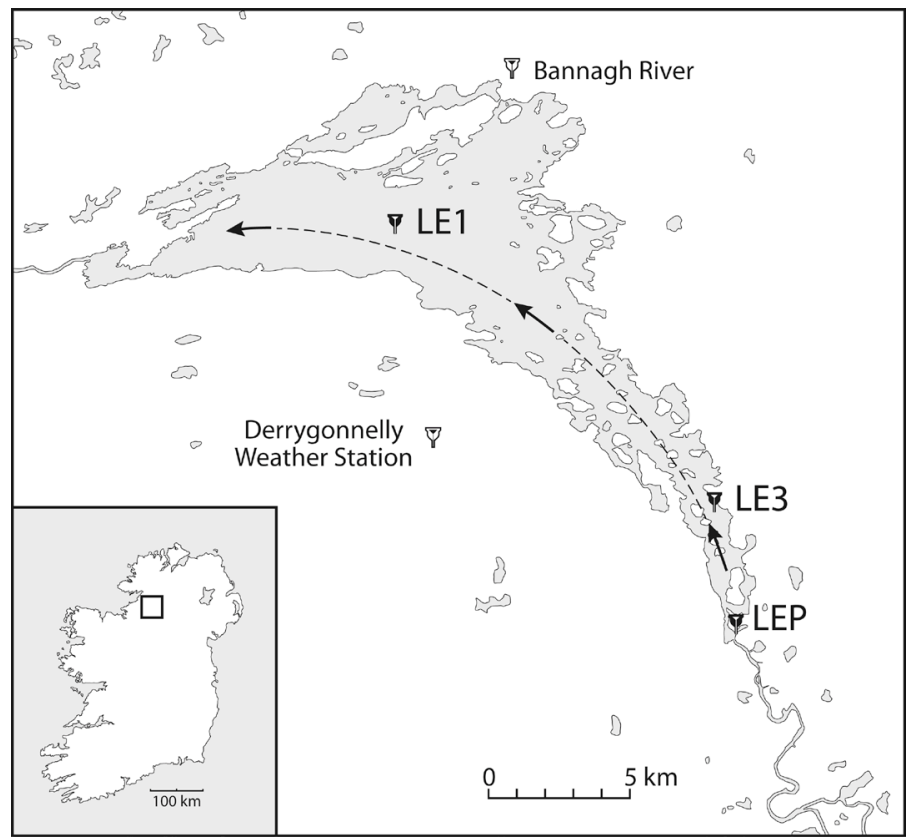

Figure 1 Lower Lough Erne, Fermanagh, Northern Ireland. Lake and river sites that were sampled are marked on the map. LE1, LE3, and LEP are represented by black markers (Table 2). Arrows show the direction of water flow.

Previous research has been conducted in the lake using stable isotope analysis (Maguire and Grey 2006) and ${ }^{14} \mathrm{C}$ analysis (Keaveney and Reimer 2012). The results of stable isotope analysis from Maguire and Grey (2006) showed that calanoid zooplankton $\delta^{13} \mathrm{C}$ and $\delta^{15} \mathrm{~N}$ values changed after zebra mussel (Dreissena polymorpha) invasion in the late 1990s, displaying increased reliance on terrestrial carbon with seasonal variation. The stable isotope research could not give any information on the age or source of terrestrial carbon utilized by biota in the lake. However, previous ${ }^{14} \mathrm{C}$ measurements suggested that the age of carbon subsidizing the food web was variable. Keaveney and Reimer (2012) demonstrated that although ${ }^{14} \mathrm{C}$ depletion was evident, related to the alkalinity of the lake, values were more enriched than expected due to terrestrial inputs to the lake. Further research was therefore needed to investigate the source and age of carbon in the lake to determine what was removed from downstream transport through burial. This study was carried out to build upon research previously undertaken in Lower Lough Erne, and to clarify the carbon dynamics in this complex lake. 
Lough Erne is comprised of an upper and lower Lough and is the second biggest lake system in Northern Ireland. Lower Lough Erne (Figure 1, Tables 1 and 2) is downstream from the Upper Lough; $80 \%$ of water flow is from the River Erne via the Upper Lough. It has a surface area of $109 \mathrm{~km}^{2}$, a catchment area of $4200 \mathrm{~km}^{2}$, a maximum depth of $55 \mathrm{~m}$, and a water residence time of $0.45 \mathrm{yr}$. The lake is alkaline and eutrophic, with concentrations of total phosphorus (TP) $>50 \mu \mathrm{g} \mathrm{L}^{-1}$ since 1975 (Gibson et al. 1980, 2003, 2005; Battarbee 1986; Foy et al. 1993). The lake catchment $\left(4200 \mathrm{~km}^{2}\right)$ drains a predominately lowland glaciated drumlin landscape with gleyed soils, which are predominantly used for grass production and beef production. The geology is dominated by Carboniferous limestone, and Carboniferous, Silurian, and Ordovician sandstones and shales.

Table 1 Attributes of Lower Lough Erne study site (Zhou et al. 2000; Gibson et al. 2005).

\begin{tabular}{ll}
\hline Lake surface area & $109 \mathrm{~km}^{2}$ \\
Max depth & $55 \mathrm{~m}$ \\
Thermocline & $30 \mathrm{~m}$ \\
Residence time & $0.45 \mathrm{yr}$ \\
Catchment size & $4200 \mathrm{~km}^{2}$ \\
Summer stratification & Weak \\
Thermocline duration & May/June to July/August \\
(Upper Lough Erne residence time)* $^{*}$ & 28 days \\
\hline
\end{tabular}

*Environmental Change Network and R Foy (personal communication).

Table 2 Coordinates of Upper and Lower Lough Erne, River Bannagh, and Derrygonnelly weather station sampling sites (Figure 1).

\begin{tabular}{ll}
\hline Site ID & Coordinates \\
\hline River Bannagh & $54^{\circ} 32^{\prime} 02^{\prime \prime} \mathrm{N}, 7^{\circ} 46^{\prime} 55^{\prime \prime} \mathrm{W}$ \\
LE1 & $54^{\circ} 29^{\prime} 07^{\prime \prime} \mathrm{N}, 7^{\circ} 50^{\prime} 37^{\prime \prime} \mathrm{W}$ \\
LE3 & $54^{\circ} 23^{\prime} 51^{\prime \prime} \mathrm{N}, 7^{\circ} 40^{\prime} 12^{\prime \prime} \mathrm{W}$ \\
LEP & $54^{\circ} 21^{\prime} 30^{\prime \prime} \mathrm{N}, 7^{\circ} 39^{\prime} 40^{\prime \prime} \mathrm{W}$ \\
Derrygonnelly Weather station & $54^{\circ} 25^{\prime} 04^{\prime \prime} \mathrm{N}, 7^{\circ} 49^{\prime} 20^{\prime \prime} \mathrm{W}$ \\
Lower Lough Erne 2014 & $54^{\circ} 27^{\prime} 10^{\prime \prime} \mathrm{N}, 7^{\circ} 44^{\prime} 28^{\prime \prime} \mathrm{W}$ \\
Upper Lough Erne 2014 & $54^{\circ} 13^{\prime} 01^{\prime \prime} \mathrm{N}, 7^{\circ} 31^{\prime} 41^{\prime \prime} \mathrm{W}$ \\
\hline
\end{tabular}

During 2000 and 2001, a population explosion of the zebra mussel lowered lake and inflowing chlorophyll $a$ by $\sim 80 \%$ and low chlorophyll $a$ concentrations that persisted in measurements taken during the study period in 2011 (Table 3; Keaveney et al. 2015 [this issue]). Although these algal reductions resulted in marked increases in water transparency, the presence of peat stain in the Lough water resulted in Secchi depths $<3 \mathrm{~m}$. Summary mean concentrations for total phosphorus, soluble reactive phosphorous, and total oxidized nitrogen for 2011 are listed in Table 3.

Weak summer stratification does periodically occur although the lake did not stratify during the study. Approximately $80 \%$ of the annual inflow is via the River Erne that enters the lake at Portora. The cumulative flow from 26 February to 26 August was equivalent to 0.54 lake volumes compared to a flow equivalent to 2.5 lake volumes for the whole of 2011; inflow to the lake is low relative to the volume of the lake. The lake lies on an approximate southeast to northwest axis; downstream from Portora the lake gradually widens into a flooded drumlin landscape with many islands and shallow depths $(<10 \mathrm{~m})$. 
Table 3 Attributes of Lower Lough Erne sampling sites provided by the Agricultural Food and Biosciences Institute (AFBI); $p \mathrm{CO}_{2}$ measurements courtesy of Christopher Barry.

\begin{tabular}{lllll}
\hline & & \multicolumn{3}{c}{ Direction of flow $\rightarrow$} \\
\cline { 3 - 5 } Attribute & Units & LEP & LE3 & LE1 \\
\hline Chlorophyll $a$ & $\mathrm{mg} \mathrm{L}^{-1}$ & 3.1 & 7.6 & 2.1 \\
Total phosphorous & $\mathrm{mg} \mathrm{L}^{-1}$ & 67 & 77 & 54 \\
Soluble reactive phosphorus & $\mathrm{mg} \mathrm{L}^{-1}$ & 36 & 35 & 36 \\
Total oxidized nitrogen & $\mathrm{mg} \mathrm{L}^{-1}$ & 296 & 328 & 646 \\
pH & & 7.8 & 7.96 & 8.03 \\
Conductivity & $\mathrm{mS} \mathrm{cm}^{-1}$ & 239 & 235 & 230 \\
Alkalinity & $\mathrm{meq} \mathrm{L}^{-1}$ & 1.72 & 1.68 & 1.58 \\
$p \mathrm{CO}_{2}$ & $\mathrm{matm}^{2}$ & 1517 & 1147 & 696 \\
DOC & $\mathrm{mg} \mathrm{L}$ & 19.9 & 19.8 & 16.9 \\
Secchi disc & $\mathrm{m}$ & 1.3 & 1.3 & 2.3 \\
\hline
\end{tabular}

Samples were collected from a boat at three sites in the Lower Lough, abbreviated as LEP, LE3, and LE1 (Figure 1), during 2011. The LEP sampling site is located where the River Erne enters at Portora, LE3 is $3 \mathrm{~km}$ downstream from LEP, and LE1 is $15 \mathrm{~km}$ further downstream. LE1 corresponds to the open-water site known as the Broad Lough and is located at the deepest part of the lake $(55 \mathrm{~m})$. The hydro-geomorphology of the lake suggests that there is minimal water movement from the Broad Lough upstream towards the inflow at Portora, evidenced by the distinct phytoplankton floras of the Broad Lough in comparison to upstream shallow areas (Gibson et al. 1980; Batterbee 1984). DIC from one Upper Lough site was measured in 2014 (see Table 2 for location data).

\section{Field Sampling for Isotopic Analyses}

Field sampling for isotopic analyses was conducted in the Lower Lough in February, March, May, July, August, and October of 2011. Additional DIC samples were obtained from the Upper Lough and Lower Lough in July 2014. Water samples for stable isotope and ${ }^{14} \mathrm{C}$ DIC, DOC, and POC analyses were taken in acid-washed $(10 \% \mathrm{HCl}) \mathrm{Nalgene}{ }^{\circledR}$ polyethylene bottles prerinsed with lake water. Samples were collected under water and care was taken to ensure exposure to air was minimal. DIC was obtained by adding $\mathrm{BaCl}_{2}$ followed by $\mathrm{NaOH}$ in the field to precipitate $\mathrm{BaCO}_{3}$ (Landmeyer and Stone 1995). Plankton and invertebrate samples were collected at all sampling sites by vertical net tows of the water column (63- and 250- $\mu \mathrm{m}$ mesh sizes, respectively). In order to achieve sufficient matter for isotopic analysis, nets were trawled behind the boat during the winter months when plankton abundances were low.

\section{Laboratory Pretreatment}

POC was filtered onto Whatman ${ }^{\circledR}$ glass fiber filters (Grade C with nominal pore size $1.2 \mathrm{um}$ ), which had been combusted overnight at $500^{\circ} \mathrm{C}$. The filters were cut in two and acidified; one half was used for stable isotope analysis and one half for ${ }^{14} \mathrm{C}$ measurement. DOC was obtained by concentrating the sampled lake water using rotary evaporation; DOC was then separated for stable isotope and ${ }^{14} \mathrm{C}$ measurement. Algal and invertebrate samples were halved for stable isotope and ${ }^{14} \mathrm{C}$ measurements; invertebrate samples were homogenized prior to analysis using a Retsch MM200 Mixer Mill. $\mathrm{BaCO}_{3}$ precipitate was filtered from lake water samples and collected on filters for DIC measurement (detailed pretreatment methods for all samples can be found in the online supplemental information). 


\section{Radiocarbon Measurement}

Invertebrate, algae, $\mathrm{POC}$, and DOC samples were loaded into precombusted quartz tubes with silver and copper oxide, sealed under vacuum, and combusted at $850^{\circ} \mathrm{C}$ overnight to generate $\mathrm{CO}_{2}$ gas. DIC samples were acidified with $86 \%$ orthophosphoric acid and the $\mathrm{CO}_{2}$ gas was cryogenically collected.

\section{Stepped Combustion}

Stepped combustion followed the method of McGeehin et al. (2001). Bulk sediment samples were halved, acidified with $4 \% \mathrm{HCl}$, and dried; 1 aliquot was combusted normally at $850^{\circ} \mathrm{C}$ overnight. The second aliquot was initially combusted at $400^{\circ} \mathrm{C}$ overnight before the $\mathrm{CO}_{2}$ produced from the low-temperature combustion was collected. The remainder of the sample was recombusted at $850^{\circ} \mathrm{C}$ overnight and gas produced from the high-temperature combustion was again collected.

\section{Graphitization and AMS Analysis}

$\mathrm{CO}_{2}$ gas collected from each sample was graphitized in the presence of an iron catalyst at $560^{\circ} \mathrm{C}$ for $4 \mathrm{hr}$ according to the Bosch-Manning hydrogen reduction method (Manning and Reid 1977; Vogel et al. 1984) and analyzed on a 0.5MV National Electrostatics compact accelerator mass spectrometer (AMS) at the ${ }^{14} \mathrm{CHRONO}$ Centre in Queen's University Belfast. The ${ }^{14} \mathrm{C} /{ }^{12} \mathrm{C}$ ratio of the sample relative to an international standard $\left(\mathrm{F}^{14} \mathrm{C}\right)$ and its associated uncertainty were calculated according to Reimer et al. (2004) and van der Plicht and Hogg (2006) and incorporated a fractionation correction (Stuiver and Polach 1977) based on $\delta^{13} \mathrm{C}$ measured by AMS.

$\Delta^{14} \mathrm{C}$ is defined in Stuiver and Polach (1977) as the relative difference between the absolute international standard (base year 1950) and sample ${ }^{14} \mathrm{C} /{ }^{12} \mathrm{C}$ ratio corrected for age and $\delta^{13} \mathrm{C}$ fractionation. The $\Delta^{14} \mathrm{C}$ age correction accounts for decay that took place between collection/death and the time of measurement, which is calculated using the equation

$$
\Delta^{14} \mathrm{C}=\left[\mathrm{F}^{14} \mathrm{C} * \mathrm{e}^{\lambda(1950-x)}-1\right] * 1000
$$

where $x$ is the year of growth (2011 for this study) and $\mathrm{F}^{14} \mathrm{C}$ is the ratio of the sample ${ }^{14} \mathrm{C} /{ }^{12} \mathrm{C}$ and standard ${ }^{14} \mathrm{C} /{ }^{12} \mathrm{C}$, both corrected for isotope fractionation (Reimer et al. 2004).

The AMS $\delta^{13} \mathrm{C}$ values include any fractionation that may occur during sample preparation and AMS analysis. These values are used for fractionation correction only, so will not be further discussed here. All other stable isotope measurements were made using a Thermo Scientific Delta V Advantage EA-IRMS. Samples were corrected using a one-point calibration with the standard IA-R041 L-alanine $\left(\delta^{13} \mathrm{C}=-23.33 \%\right.$; $\delta^{15} \mathrm{~N}=-5.56 \%$ ). Two other standards were measured at intervals: USGS41 L-glutamic acid $\left(\delta^{13} \mathrm{C}=+37.63 \% ; \delta^{15} \mathrm{~N}=+47.57 \%\right)$ and leucine $\left(\delta^{13} \mathrm{C}=-30.52 \% ; ; \delta^{15} \mathrm{~N}=\right.$ $+10.77 \%$ ) and results plotted to make a two-point calibration. The effect of applying one-point and two-point correction to samples was compared and the difference was negligible. The precision of the EA-IRMS is $<0.1 \%$ for $\delta^{13} \mathrm{C}$ and $<0.15 \%$ of $\delta^{15} \mathrm{~N}$.

\section{Lake Water Analyses}

During the study period and at approximately 14-day intervals, surface water samples were taken at each site together with a 0-10 m integrated sample at the LE1 site as set out by Foy et al. (1993). Sampling included in situ measurements of lake water temperature and Secchi disc depth. On return to the laboratory, samples were analyzed for chlorophyll $a$, nutrients, alkalinity, and $\mathrm{pH}$ using standard methods as described by Girvan and Foy (2006). Summary mean values for the period 2011 are listed in Table 3 plus means for lake water DOC, which was determined within $24 \mathrm{hr}$ by 
Pt-catalyzed combustion (Teledyne Techmar Apollo 9000 TOC analyzer). Between January and September 2011, nine sets of in situ measurements of carbon dioxide partial pressure $\left(p \mathrm{CO}_{2}\right)$ in surface water ( $0.4 \mathrm{~m}$ depth) were also using an EGM-4 portable infrared gas analyzer (PP Systems, UK).

\section{RESULTS}

Comprehensive tables of results can be found in the online supplemental information.

\section{Inorganic Carbon and Autotrophic Producers}

Carbon sources (terrestrial and/or rock-derived) supporting the inorganic carbon pool can be examined using DIC $\Delta^{14} \mathrm{C}$. Values are spatially and temporally variable in Lower Lough Erne. DIC $\Delta^{14} \mathrm{C}$ should be depleted relative to the contemporary atmosphere caused by the hardwater effect due to the carbonate alkalinity of the lake (expected value $\Delta^{14} \mathrm{C} \approx-63 \%$, Keaveney and Reimer 2012). However, the spatial and temporal variation seen in Figure 2 is different from the DIC value expected from the consistent alkalinity of the lake water. There is substantial enrichment of DIC ${ }^{14} \mathrm{C}$ values (Figure 2) measured from LE1 in May $\left(\Delta^{14} \mathrm{C}=-20.0 \pm 3.6 \%\right.$ ) relative to those measured in February and March $\left(\Delta^{14} \mathrm{C}=-55.5 \pm 3.0 \%\right.$ and $-54.4 \pm 3.1 \%$, respectively $)$.

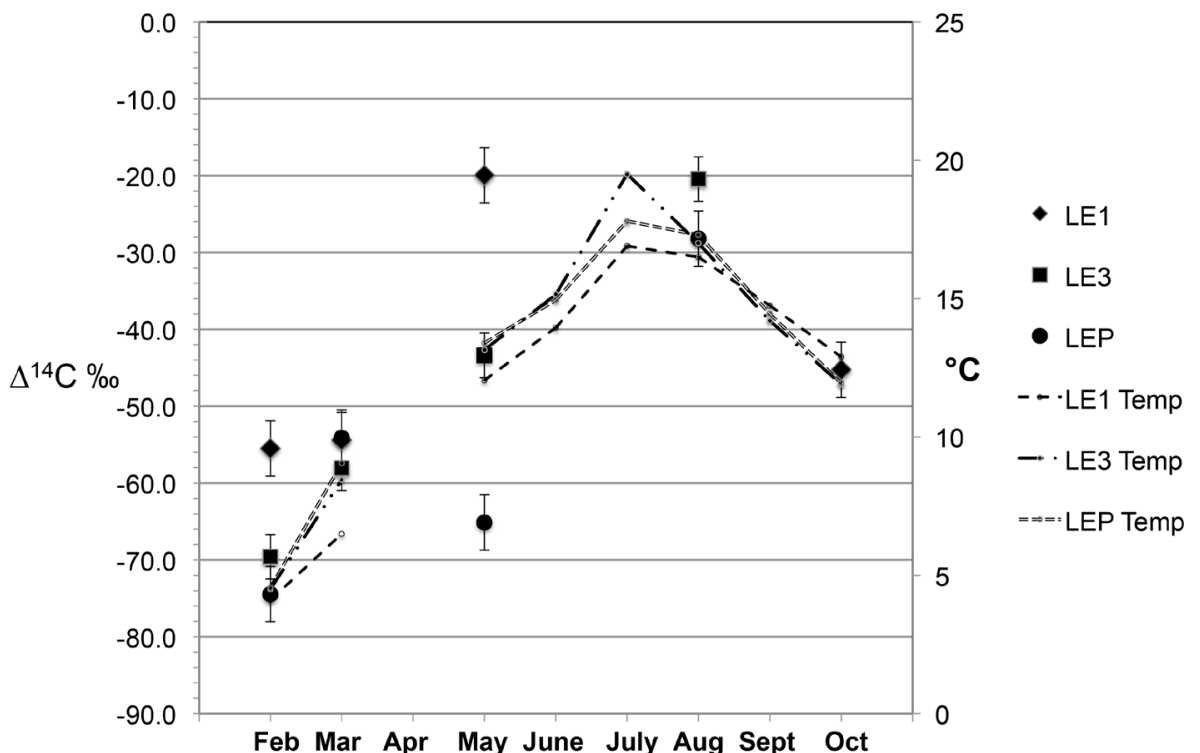

Figure 2 DIC $\Delta^{14} \mathrm{C}$ values (supplemental information) plotted with average monthly lake water temperatures from each site. Error bars correspond to $1 \sigma$ uncertainty on $\Delta^{14} \mathrm{C}$ measurements.

There is also spatial variation in DIC $\Delta^{14} \mathrm{C}$. LE3 and LEP values are more depleted than LE1 $\left(\Delta^{14} \mathrm{C}=-65.8 \pm 6.6 \%\right.$ and $-64.6 \pm 10.2 \%$, respectively $)$. Both become enriched in August $\left(\Delta^{14} \mathrm{C}=\right.$ $-20.5 \pm 3.5 \%$ and $-28.2 \pm 3.9 \%$, respectively). DIC $\Delta^{14} \mathrm{C}$ from Upper Lough Erne (Table 2 ) measured in July 2014 is comparable to that of samples collected from LE3 and LEP in February 2011 $\left(\Delta^{14} \mathrm{C}=-76.3 \pm 4.5 \%\right)$.

The temporal and spatial variability evident in DIC values was not present in algal $\Delta^{14} \mathrm{C}$ values (Figure 3) collected in the year of study on the same day as DIC and other samples $\left(\Delta^{14} \mathrm{C}=\right.$ $-50.4 \pm 22.1 \%$ ). Samples collected in May (dominated by cyanobacteria) were ${ }^{14} \mathrm{C}$-depleted $\left(\Delta^{14} \mathrm{C}=\right.$ $-93.4 \pm 4.5 \%$ ) relative to DIC ${ }^{14} \mathrm{C}$ (mean DIC from all sites in May: $\Delta \Delta^{14} \mathrm{C}=-51.6 \pm 27.5 \%$ ) and algae collected throughout the year. Cyanobacteria collected in August $\left(\Delta^{14} \mathrm{C}=-57.9 \pm 3.9 \%\right)$ were ${ }^{14} \mathrm{C}$-enriched relative to the single depleted May sample value. Algal samples collected in February 
when algal abundance was low (mean $\Delta \Delta^{14} \mathrm{C}=-51.5 \pm 29.6 \%$ ) were dominated by cyanobacteria and are consistent with August measurements.

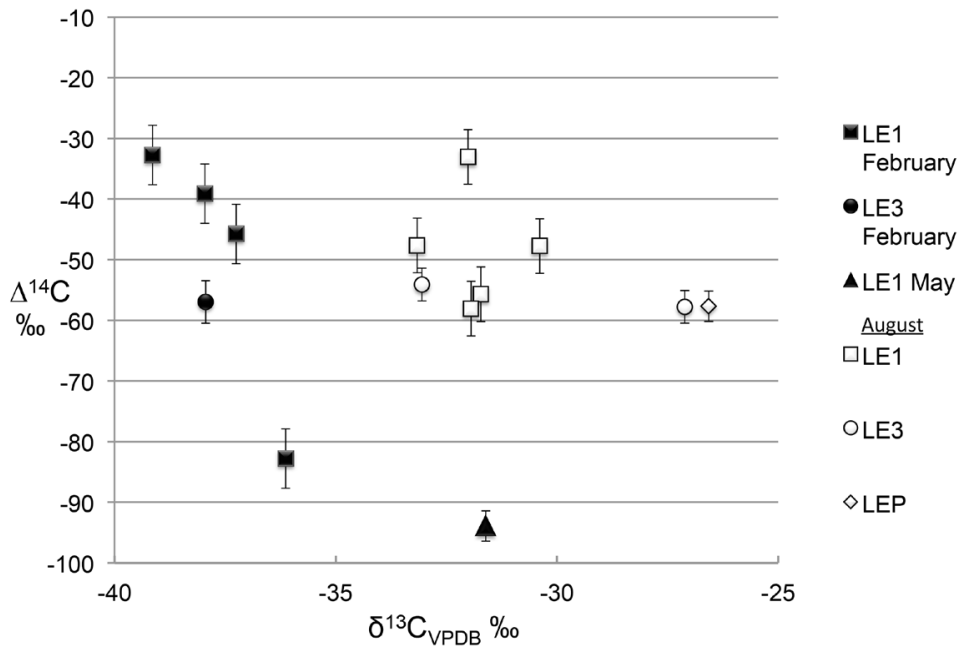

Figure 3 Algae and cyanobacteria carbon isotope values. Samples were collected in February, May, and August 2011. The samples in February and May were difficult to analyze due to low algal abundance but were dominated by cyanobacteria. Increased algal abundance allowed separation of species in August (supplemental information). Error bars correspond to $1 \sigma$ uncertainty on $\Delta^{14} \mathrm{C}$ measurements.

\section{Terrestrial Carbon}

DOC samples taken from the lake are ${ }^{14} \mathrm{C}$-enriched relative to other carbon pools, and, although DOC $\Delta^{14} \mathrm{C}$ is variable over the sampling period (mean $\Delta^{14} \mathrm{C}=-16.5 \pm 8.6 \%$, Figure 4), values are also equivalent to POC and DOC samples from the tributary River Bannagh $\left(\triangle^{14} \mathrm{C}=-29.9 \pm 8.2 \%\right.$ and $-16.7 \pm 3.0 \%$, respectively). A positive $\Delta^{14} \mathrm{C}$ signature was measured in DOC collected from the River Bannagh in October $\left(+50 \pm 2.9 \%\right.$ ). POC samples are consistently more ${ }^{14} \mathrm{C}$-depleted (mean $\Delta{ }^{14} \mathrm{C}=-122.3 \pm 32.6 \%$ ) than other samples.

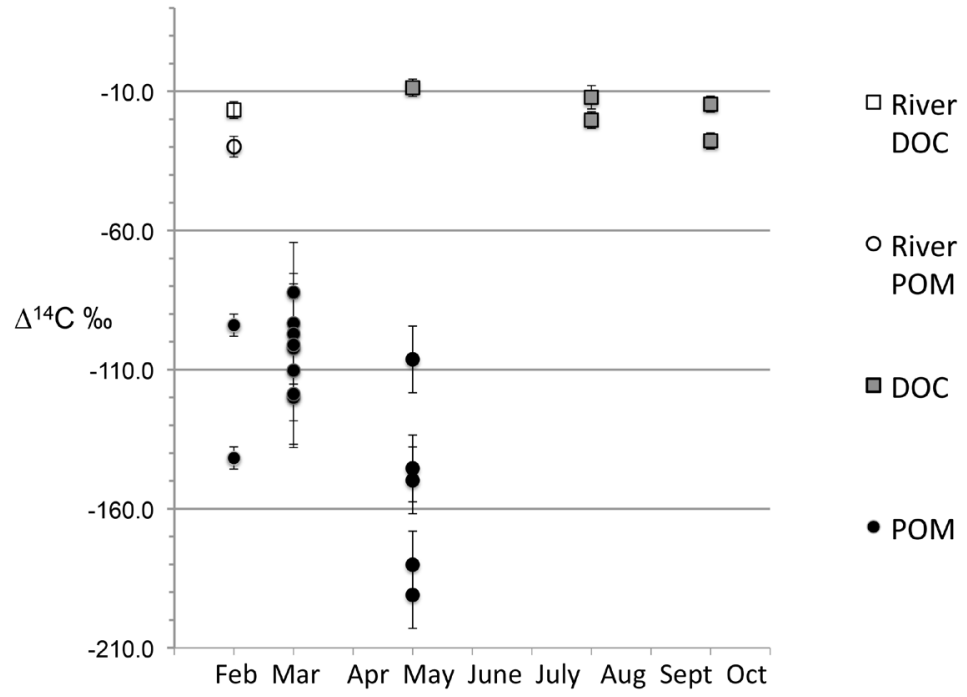

Figure $4 \quad \Delta^{14} \mathrm{C}$ values of DOC and POC collected from Lower Lough Erne and River Bannnagh in 2011. Error bars correspond to $1 \sigma$ uncertainty on $\Delta^{14} \mathrm{C}$ measurements. 


\section{Lake Sediment: Stepped Combustion}

Stepped combustion of lake surface sediment yielded distinct $\Delta^{14} \mathrm{C}$ values (Figure 5). Figure 6 illustrates the difference between the samples. Samples that combusted at a higher temperature were ${ }^{14} \mathrm{C}$-depleted $\left(\Delta{ }^{14} \mathrm{C}=-167.2 \pm 3.7 \% 0,-173.4 \pm 3.7 \%\right)$ relative to bulk sediment samples $\left(\Delta^{14} \mathrm{C}=\right.$ $-134.0 \pm 3.9 \%,-127.3 \pm 3.5 \%$, Table 5$)$. The sample combusted at $400{ }^{\circ} \mathrm{C}$ was ${ }^{14} \mathrm{C}$-enriched $\left(\Delta^{14} \mathrm{C}=\right.$ $-68.1 \pm 3.6 \%$ o) relative to the bulk sediment.

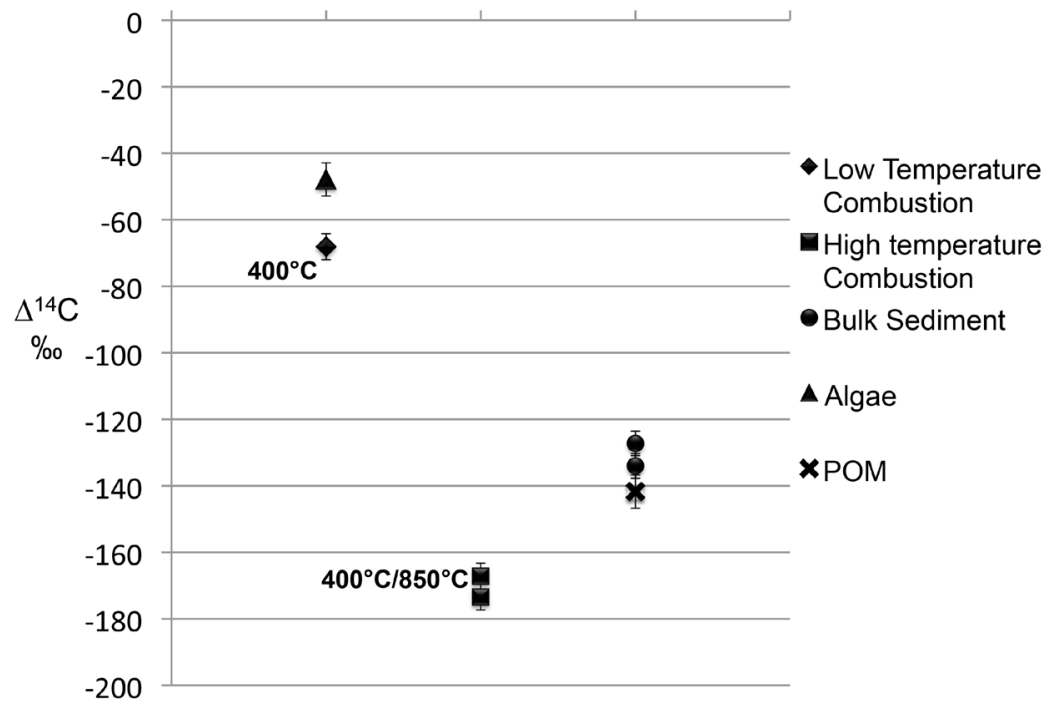

Figure $5 \quad \Delta^{14} \mathrm{C}$ values of Lower Lough Erne sediment compared with algae and POC values. Error bars correspond to $1 \sigma$ uncertainty on $\Delta^{14} \mathrm{C}$ measurements.

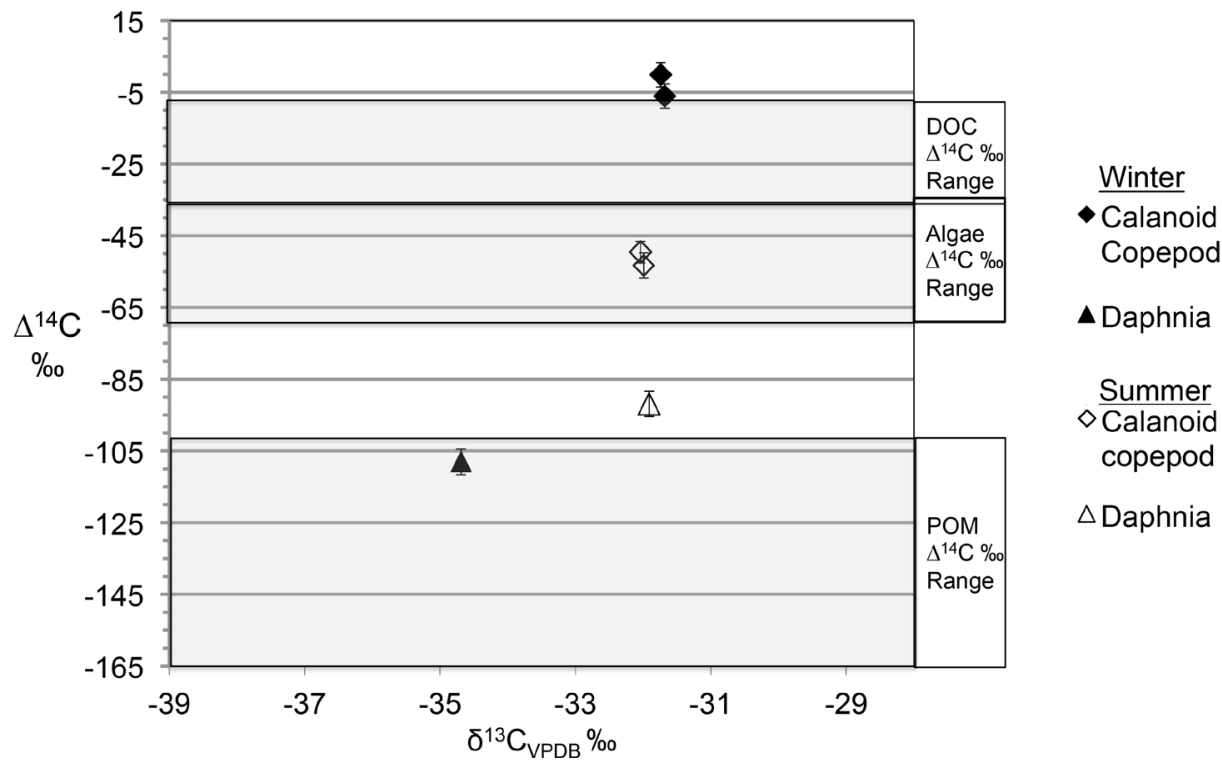

Figure 6 Invertebrate $\Delta^{14} \mathrm{C}$ and $\delta^{13} \mathrm{C}$ values of selected Lower Lough Erne zooplankton. Winter samples were collected in February and March, and summer samples in August 2011. Error bars correspond to $1 \sigma$ uncertainty on $\Delta^{14} \mathrm{C}$ measurements. 


\section{Invertebrate Community}

The zooplankton measured comprised calanoid zooplankton (Eudiaptomus gracilis) and Daphnia spp. Other invertebrates were also collected but sample size was relatively small. Seasonal variation and differences in carbon source were evident in selected invertebrates presented in this study.

Herbivorous calanoid zooplankton $\Delta^{14} \mathrm{C}$ values (Figure 6) were enriched relative to the $\Delta^{14} \mathrm{C}$ signature of their preferred food source, algae. The mean calanoid zooplankton $\Delta^{14} \mathrm{C}(-4.0 \pm 6.1 \%)$ collected in winter is enriched relative to that in the summer $\left(\Delta^{14} \mathrm{C}=-50 \pm 4.1 \%\right)$. The summer values are equivalent to algal $\Delta^{14} \mathrm{C}$; winter values are equivalent to lake DOC, suggesting a change in the food source. Daphnia $\Delta^{14} \mathrm{C}$ values were depleted relative to anything else in the invertebrate community (mean $\Delta \Delta^{14} \mathrm{C}=-100 \pm 11.5 \%$ ); they were, however, in the range of subfossil POC $\Delta^{14} \mathrm{C}$.

\section{DISCUSSION}

The $\Delta^{14} \mathrm{C}$ values of DIC, DOC, and POC collected from Lower Lough Erne in February indicate that there is a significant difference in age of carbon among these three pools: enriched (modern, recent, subsurface) DOC, depleted (subfossil) POC, and intermediate (geological) DIC values. Invertebrate species utilized carbon from all three pools; sediment $\Delta^{14} \mathrm{C}$ indicated that bulk samples were dominated by subfossil terrestrial carbon.

\section{Inorganic Carbon Pool}

The DIC $\Delta^{14} \mathrm{C}$ seen in Lower Lough Erne is enriched relative to the value predicted by Keaveney and Reimer $(2012)$ from the carbonate alkalinity of the lake $(\approx-63 \%)$. Temporal variation is clear as $\Delta^{14} \mathrm{C}$ values of DIC from sites in August are considerably enriched relative to this value. It is difficult to explain the variation in DIC $\Delta{ }^{14} \mathrm{C}$ particularly when the hydrology of the lake is examined. Some $80 \%$ of the flow is via the River Erne from the Upper Lough and water flows from $\mathrm{LEP} \rightarrow \mathrm{LE} 3 \rightarrow \mathrm{LE} 1 ;{ }^{14} \mathrm{C}$ signals should reflect those of the Upper Lough.

The Upper Lough is dominated by macrophytes. Their proliferation and utilization of inorganic carbon may lead to incursion of atmospheric $\mathrm{CO}_{2}$ when lake $p \mathrm{CO}_{2}$ drops below atmospheric levels (Bornette and Puijalon 2011). However, DIC values measured in Upper Lough Erne in 2014 are more ${ }^{14} \mathrm{C}$-depleted $\left(\Delta^{14} \mathrm{C}=-76.3 \pm 4.5 \%\right)$ than any of the Lower Lough Erne values measured in 2011.

A decrease in $p \mathrm{CO}_{2}$ values was observed along the direction of flow from LEP to LE1 (Table 3), but as the lake remains supersaturated, there is no evidence to suggest that DIC $\Delta^{14} \mathrm{C}$ enrichment/ depletion is related to $\mathrm{CO}_{2}$ transfer between the lake and the atmosphere. DIC $\Delta^{14} \mathrm{C}$ was enriched at all sites in summer months when all sites were supersaturated, precluding the possibility that atmospheric incursion was responsible for enrichment in the Lower Lough.

There is an insignificant pattern $\left(R^{2}=0.32\right)$ of enrichment of DIC $\Delta{ }^{14} \mathrm{C}$ values with increased lake water and atmospheric temperatures (Figure 2). While the link between temperature and DIC values in the Lough is tenuous, an atmospheric temperature increase may lead to increased subsurface soil carbon mobility (Fang et al. 2005; Winterdahl et al. 2011), which can be remineralized (by bacteria or photomineralization) and may contribute to the inorganic carbon pool (Kritzberg et al. 2006, 2014; Tranvik et al. 2013).

The turnover time of soil can vary. While labile carbon turns over rapidly, the intermediate carbon pool in soils can take decades to decompose and the more passive soil pools turnover on a centennial scale (Trumbore et al. 1989; Torn et al. 2013). Subsurface terrestrial soil exports may therefore 
incorporate bomb carbon from the last few decades. DOC containing this bomb carbon may then be rapidly remineralized once released, particularly when increased sunlight and photoperiod leads to increased photomineralization of terrestrial carbon (Tranvik et al. 2013). Thermal sensitivity of the respiration of soil carbon and subsequent increased mobility is related to microbial metabolization, which also increases with temperature (Fang et al. 2005; Liu 2013).

In order to explain enrichment of DIC $\Delta^{14} \mathrm{C}$ values from winter to summer values, highly positive bomb $\Delta{ }^{14} \mathrm{C}$ must be introduced to the DIC pool. Some $80 \%$ of the flow of water to the lake is from the River Erne, yet DIC measured from the river $(n=1)$ is ${ }^{14} \mathrm{C}$-depleted (as is the Upper Lough); the source of ${ }^{14} \mathrm{C}$ enrichment in the Lower Lough therefore cannot be autochthonous. The source of enrichment of DIC $\Delta^{14} \mathrm{C}$ can only be derived from the remaining $20 \%$ of the water input to the lake from the catchment.

The following simple mass balance model was used to estimate the $\Delta^{14} \mathrm{C}$ value required to enrich LE1 DIC $\Delta^{14} \mathrm{C}$ in August (the most positive DIC $\Delta^{14} \mathrm{C}$ value in our study):

$$
Z_{L A K E}=Z_{A L K}(1-X)+X\left(Z_{\text {SOURCE }}\right)
$$

where $Z_{L A K E}$ is the measured DIC $\Delta^{14} \mathrm{C}$ from sample UBA-17857 $\left(\Delta^{14} \mathrm{C}=-20 \%\right), Z_{A L K}$ is the DIC $\Delta^{14} \mathrm{C}$ value $\left(\Delta^{14} \mathrm{C}=-63 \%\right)$ estimated from the water alkalinity (Keaveney and Reimer 2012$)$, and $Z_{\text {SOURCE }}$ is the source end member.

Three different source end members were employed to estimate which is the most likely source of enriched ${ }^{14} \mathrm{C}$ (Table 4). Atmospheric $\mathrm{CO}_{2} \Delta{ }^{14} \mathrm{C}$ was obtained from the literature (Levin et al. 2013). River DOC measured in October (UBA-20706, see online supplemental information) had a positive $\Delta^{14} \mathrm{C}$ value, so was selected to represent modern photosynthetic carbon derived from autumnal leaf fall. Given that catchment inflow to the lake is low $(20 \%)$, the models utilizing modern atmospheric and riverine DOC end members require unreasonably large contributions to result in the DIC $\Delta^{14} \mathrm{C}$ values measured from Lower Lough Erne. Subsurface soil was not measured, but the end member value was chosen from values observed in soil carbon turnover studies (Koarashi et al. 2012; Torn et al. 2013; Trumbore and Schrumpf 2013), which resulted in a percent contribution that matched the catchment flow of $20 \%$.

Table 4 Components of mass balance model to determine causes of DIC $\Delta{ }^{14} \mathrm{C}$ enrichment.

\begin{tabular}{|c|c|c|c|c|c|}
\hline & End member & $Z_{\text {LAKE }}$ & $Z_{\text {SOURCE }}$ & $Z_{A L K}$ & \\
\hline Model & Model source & UBA-17857 DIC $\Delta^{14} \mathrm{C}$ & $\Delta^{14} \mathrm{C}$ source & $\Delta^{14} \mathrm{C}$ lake DIC & $\%$ contribution \\
\hline 1 & Atmospheric & -20 & 40 & -63 & 42 \\
\hline 2 & River DOC & -20 & 50 & -63 & 38 \\
\hline 3 & River Erne & -20 & -40 & -63 & -87 \\
\hline 4 & Subsurface soil & -20 & 152 & -63 & 20 \\
\hline
\end{tabular}

A hypothetical $\Delta^{14} \mathrm{C}$ value of $152 \%$ results in a $20 \%$ contribution, matching the observed catchment flow rate. This bomb $\Delta^{14} \mathrm{C}$ value can only be sourced from subsurface soil stocks (Koarashi et al. 2012; Torn et al. 2013), the contribution of which may fluctuate seasonally. Previously sequestered terrestrial carbon may be exported as temperatures increase in the summer, leading to DIC enrichment measured in the lake. 


\section{Algal Production - Utilizing Terrestrial Carbon?}

With a few exceptions, algal $\Delta^{14} \mathrm{C}$ values (mean $\Delta^{14} \mathrm{C}=-50.4 \pm 13.3 \%$ ) are more consistent both spatially and temporally (Figure 3 ), yet some are enriched relative to the value $\left(\Delta^{14} \mathrm{C} \approx-63 \%\right.$ ) predicted from Keaveney and Reimer (2012). This indicates that algae are also relying on the inorganic pool partially derived from terrestrial carbon, although algal $\Delta{ }^{14} \mathrm{C}$ values are less variable than DIC $\Delta^{14} \mathrm{C}$.

Algal (dominated by cyanobacteria) $\Delta^{14} \mathrm{C}$, collected in May, is significantly $(>2 \sigma)$ more depleted $(-93.9 \pm 4.5 \%)$ than that of DIC collected in May, or other algal samples collected in February and August. Terrestrial POC may have been introduced into the bulk algal sample during filtration from lake water when algal abundance was low, possibly explaining the depleted $\Delta^{14} \mathrm{C}$ value.

\section{Organic Carbon Pools}

The influence of terrestrial carbon is clearly evident in the organic carbon pools (DOC and POC, Figure 4). Enriched (modern and/or recent surface) terrestrial carbon is found in the DOC pool and depleted (subfossil) in the POC pool. Organic carbon pools in Lower Lough Erne are predominantly derived from terrestrial sources, as evidenced by the $\Delta^{14} \mathrm{C}$ values.

$\Delta{ }^{14} \mathrm{C}$ values are enriched in DOC samples relative to the other carbon pools and are consistent spatially and temporally over the sampling period (Figure 4). They are also equivalent to DOC and POC samples from the tributary River Bannagh. The DOC pool is therefore seen as representative of terrestrial carbon, originating from surface soil/peat, probably entering the lake via tributary rivers. The negative $\Delta^{14} \mathrm{C}$ values indicate they are probably derived from recently deposited leaf litter/soil carbon that has undergone some decay.

$\triangle^{14} \mathrm{C}$ values of POC samples are consistently depleted compared to other samples, indicating they are derived from subfossil detrital terrestrial carbon (Figure 4). POC also likely contains a more modern source of carbon as well as subfossil carbon (possibly explaining variation seen in $\Delta^{14} \mathrm{C}$ values of different samples) as indicated by stepped-combustion analysis of sediment.

The low-temperature stepped-combustion fraction yielded measurements with $\Delta^{14} \mathrm{C}$ values equivalent to those from algae, while the high-temperature fraction subfossil values were more ${ }^{14} \mathrm{C}$-depleted than terrestrial POC. The bulk sediment sample $\Delta{ }^{14} \mathrm{C}$ suggests that $64 \%$ of the buried carbon, which is more depleted than anything else in the lake, was derived from a detrital subfossil terrestrial source. It is also likely that POC is comprised of subfossil and labile carbon given its depleted $\Delta^{14} \mathrm{C}$ value, equivalent to that of bulk sediment.

\section{Carbon Sources of the Invertebrate Community - Autochthonous or Terrestrial?}

Stable isotope values of Lower Lough Erne invertebrates measured in the current study support the assertion of Maguire and Grey (2006) that terrestrial carbon is utilized by calanoid species in the lake; ${ }^{15} \mathrm{~N}$ values of calanoid copepods measured in this study are enriched more than anything else in the food web. This indicates the presence of a microbial loop with bacteria metabolizing terrestrial carbon for use by other species. However, the stable isotope results do not indicate whether the terrestrial source carbon source is DOC or detrital POC.

E. gracilis is an herbivorous calanoid copepod that usually feeds on phytoplankton. In winter months, when algal abundance is low, E. gracilis can supplement its diet with terrestrial carbon. Rautio et al. (2011) showed that the $\delta^{13} \mathrm{C}$ of calanoid copepods did not track the $\delta^{13} \mathrm{C}$ values of the POC, suggesting that they did not consume carbon from the POC pool in oligotrophic subarctic Lake Saanajärvi. The $\Delta^{14} \mathrm{C}$ of the zooplankton in Lower Lough Erne supports this assertion. It is 
consistent with that of the lake and river DOC, indicating that E. gracilis discriminates against subfossil carbon and detritus. $\Delta^{14} \mathrm{C}$ values of E. gracilis in the summer when algae are more abundant show a clear switch to an algal diet, not indicated by the stable isotope results.

Daphnia, on the other hand, which have been proven to consume bulk POC (Pulido-Villena et al. 2005), are more depleted than the algal $\Delta^{14} \mathrm{C}$. Daphnia have also been shown to feed on the algal portion of the POC (Rautio et al. 2011) but can also consume bacteria (Taipale et al. 2012). The ${ }^{15} \mathrm{~N}$ values of Daphnia measured in this study are enriched relative to POC, but also to DOC, so the food source is unclear. However, their depleted $\Delta^{14} \mathrm{C}$ values indicate that Daphnia in Lower Lough Erne are consuming a subfossil carbon source, suggesting that they may be feeding on bacteria, which are in turn consuming detrital subfossil carbon.

\section{CONCLUSION}

In this study, ${ }^{14} \mathrm{C}$ measurements have been used to determine the source of carbon utilized in the lake and the extent to which selected biota rely on terrestrial carbon support. The results of the study show that all carbon pools and hence the biota of Lower Lough Erne are supported by terrestrial carbon sources. The age of TC utilized in the food web has been determined in Lower Lough Erne, indicating that both detrital and labile TC are metabolized by invertebrates. However, sediment is predominantly derived from subfossil terrestrial carbon, indicating that exported subfossil TC may be stored in lake sediment while the majority of modern terrestrial carbon is mineralized in the food web, possibly leading to $\mathrm{CO}_{2}$ saturation and flux to the atmosphere.

Lower Lough Erne is substantially supported by terrestrial carbon. Despite its heterotrophic status, carbon is still buried and stored in sediment. Further study is required to link production rates in Lower Lough Erne with carbon burial, but it is clear that seasonality in the terrestrial support of carbon pools in the lake is present and is best identified using $\Delta^{14} \mathrm{C}$. The results from Lough Erne can be used to understand the propensity of an alkaline lake with terrestrial subsidy to be a source or store of terrestrial carbon, which in turn is linked with biotic processes in the lake. The ${ }^{14} \mathrm{C}$ method allows us to investigate the fate of catchment carbon exports in Lower Lough Erne, and globally in other lake types.

\section{ACKNOWLEDGMENTS}

We thank the staff of the ${ }^{14} \mathrm{CHRONO}$ Centre at Queen's University Belfast, particularly Stephen Hoper and Ron Reimer for aid in stepped combustion and AMS radiocarbon analysis. We also thank the staff of the Freshwater Lab and Agri-Environment Branch of AFBI who undertook lake sampling and water analyses, and in particular Chris Barry who was responsible for separating the biological samples and their identification. Chris also made available his data on DOC loading and $p \mathrm{CO}_{2}$ measurements from Lough Erne. Thanks to Barry Finnegan for additional help with sampling. Thanks also to Kendra Cheruvelil and anonymous reviewers for comments and assistance. We are happy to make our data available as supplemental information to be accessible to anyone who views the manuscript. Funding for this work was provided by the Natural Environment Research Council, UK grant NE/I01666X/1.

\section{REFERENCES}

Ågren A, Berggren M, Laudon H, Jansson M. 2008. Terrestrial export of highly bioavailable carbon from small boreal catchments in spring floods. Freshwater Biology 53(5):964-72.

Bade DL, Pace ML, Cole JJ, Carpenter SR. 2006. Can algal photosynthetic inorganic carbon isotope frac- tionation be predicted in lakes using existing models? Aquatic Sciences 68(2):142-53.

Bartels P, Cucherousset J, Gudasz C, Jansson M, Karlsson J, Persson L, Premke K, Rubach A, Steger K, Tranvik LJ. 2012. Terrestrial subsidies to lake food webs: an experimental approach. Oecologia 168(3):807-18. 
Battarbee RW. 1984. Spatial variations in the water quality of Lough Erne, Northern Ireland, on the basis of surface sediment diatom analysis. Freshwater Biology 14(5):539-45.

Battarbee RW. 1986. The eutrophication of Lough Erne inferred from changes in the diatom assemblages of ${ }^{210} \mathrm{~Pb}$ - and ${ }^{37} \mathrm{Cs}$-dated sediment cores. Proceedings of the Royal Irish Academy 86B:141-68.

Bornette G, Puijalon S. 2011. Response of aquatic plants to abiotic factors: a review. Aquatic Sciences 73(1):1-14.

Broecker WS, Orr PC. 1958. Radiocarbon chronology of Lake Lahontan and Lake Bonneville. Geological Society of America Bulletin 69(8):1009-32.

Broecker WS, Walton A. 1959. The geochemistry of $\mathrm{C}^{14}$ in fresh-water systems. Geochimica et Cosmochimica Acta 16(1-3):15-38.

Butman D, Raymond PA. 2011. Significant efflux of carbon dioxide from streams and rivers in the United States. Nature Geoscience 4:839-42.

Butman D, Raymond P, Oh N-H, Mull K. 2007. Quantity, ${ }^{14} \mathrm{C}$ age and lability of desorbed soil organic carbon in fresh water and seawater. Organic Geochemistry 38(9): 1547-57.

Butman D, Raymond PA, Butler K, Aiken G. 2012. Relationships between $\Delta^{14} \mathrm{C}$ and the molecular quality of dissolved organic carbon in rivers draining to the coast from the conterminous United States. Global Biogeochemical Cycles 26(4):GB4014, doi:10.1029/2012GB004361.

Caraco N, Bauer JE, Cole JJ, Petsch S, Raymond P. 2010. Millennial-aged organic carbon subsidies to a modern river food web. Ecology 91:2385-93.

Carpenter SR, Cole JJ, Pace ML, Van De Bogert M, Bade DL, Bastviken D, Gille CM, Hodgson JR, Kitchell JF, Kritzberg ES. 2005. Ecosystem subsidies: terrestrial support of aquatic food webs from ${ }^{13} \mathrm{C}$ addition to contrasting lakes. Ecology 86:2737-50.

Cole JJ, Carpenter SR, Pace ML, Van De Bogert MC, Kitchell JL, Hodgson JR. 2006. Differential support of lake food webs by three types of terrestrial organic carbon. Ecology Letters 9(5):558-68.

de Kluijver A, Yu J, Houtekamer M, Middelburg JJ, Liu Z. 2012. Cyanobacteria as carbon source for zooplankton in eutrophic Lake Taihu, China, measured by ${ }^{13} \mathrm{C}$ labelling and fatty acid biomarkers. Limnology and Oceanography 57(4):1245-54.

Deevey ES, Gross MS, Hutchinson GE, Kraybill HL. 1954. The natural $\mathrm{C}^{14}$ contents of materials from hard-water lakes. Proceedings of the National Academy of Sciences of the USA 40(5):285-8.

Douglas PMJ, Pagani M, Eglinton TI, Brenner M, Hodell DA, Curtis JH, Ma KF, Breckenridge A. 2014. Preaged plant waxes in tropical lake sediments and their influence on the chronology of molecular paleoclimate proxy records. Geochimica et Cosmochimica Acta 141:346-64.

Fang C, Smith P, Moncrieff JB, Smith JU. 2005. Similar response of labile and resistant soil organic matter pools to changes in temperature. Nature 433(7021):57-9.
Farquhar GD, Ehleringer JR, Hubick KT. 1989. Carbon isotope discrimination and photosynthesis. Annual Review of Plant Biology 40:503-37.

Foy RH, McGlynn K, Gibson CE. 1993. Chlorophyll a and nutrients in Lough Erne. Biology and Environment: Proceedings of the Royal Irish Academy 93B(3):163-74.

France RL. 1995. Differentiation between littoral and pelagic food webs in lakes using stable carbon isotopes. Limnology and Oceanography 40(7):13103.

Gibson C, Foy R, Fitzsimons A. 1980. A limnological reconnaissance of the Lough Erne system, Ireland. Internationale Revue der Gesamten Hydrobiologie und Hydrographie 65(1):49-84.

Gibson C, Anderson N, Zhou Q, Allen M, Appleby P. 2003. Changes in sediment and diatom deposition in Lower Lough Erne c. 1920-90. Biology and Environment: Proceedings of the Royal Irish Academy 103B(1):31-9.

Gibson C, Foy R, McNally J. 2005. Stratification and oxygen depletion in Lower Lough Erne 1991-2000. Biology and Environment: Proceedings of the Royal Irish Academy 105B(2):81-6.

Girvan J, Foy RH. 2006. Trophic stability in an Irish mesotrophic lake. Aquatic Conservation: Marine and Freshwater Ecosystems 16(6):623-6.

Grey J, Jones RI, Sleep D. 2001. Seasonal changes in the importance of the source of organic matter to the diet of zooplankton in Loch Ness, as indicated by stable isotope analysis. Limnology and Oceanography 46(3):505-13.

Gupta G, Sarma V, Robin R, Raman A, Kumar MJ, Rakesh M, Subramanian B. 2008. Influence of net ecosystem metabolism in transferring riverine organic carbon to atmospheric $\mathrm{CO}_{2}$ in a tropical coastal lagoon (Chilka Lake, India). Biogeochemistry 87(3):265-85

Heathcote AJ, Downing JA. 2012. Impacts of eutrophication on carbon burial in freshwater lakes in an intensively agricultural landscape. Ecosystems 15(1):60-70.

Ishikawa NF, Hyodo F, Tayasu I. 2013. Use of carbon-13 and carbon-14 natural abundances for stream food web studies. Ecological Research 28(5):759-69.

Ishikawa NF, Uchida M, Shibata Y, Tayasu I. 2014. Carbon storage reservoirs in watersheds support stream food webs via periphyton production. Ecology 95(5):1264-71.

Karlsson J, Jonsson A, Meili M, Jansson M. 2003. Control of zooplankton dependence on allochthonous organic carbon in humic and clear-water lakes in northern Sweden. Limnology and Oceanography 48(1):269-76

Keaveney EM, Reimer PJ. 2012. Understanding the variability in freshwater radiocarbon reservoir offsets: a cautionary tale. Journal of Archaeological Science 39(5):1306-16.

Keaveney EM, Reimer PJ, Foy RH. 2015. Young, old, and weathered carbon-Part 2: using radiocarbon and stable isotopes to identify terrestrial carbon sup- 
port of the food web in an alkaline, humic lake. $R a-$ diocarbon 57(3):425-38. [this issue].

Koarashi J, Hockaday WC, Masiello CA, Trumbore SE. 2012. Dynamics of decadally cycling carbon in subsurface soils. Journal of Geophysical Research 117:G03033, doi:10.1029/2012JG002034.

Koehler B, Landelius T, Weyhenmeyer GA, Machida N, Tranvik LJ. 2014. Sunlight-induced carbon dioxide emissions from inland waters. Global Biogeochemical Cycles 28(7):696-711.

Kritzberg ES, Langenheder S, Lindström ES. 2006. Influence of dissolved organic matter source on lake bacterioplankton structure and function-implications for seasonal dynamics of community composition. FEMS Microbiology Ecology 56(3):406-17.

Kritzberg ES, Granéli W, Björk J, Brönmark C, Hallgren P, Nicolle A, Persson A, Hansson LA. 2014. Warming and browning of lakes: consequences for pelagic carbon metabolism and sediment delivery. Freshwater Biology 59(2):325-36.

Landmeyer JE, Stone PA. 1995. Radiocarbon and $\delta^{13} \mathrm{C}$ values related to ground-water recharge and mixing. Groundwater 33(2):227-34.

Lapierre J-F, Guillemette F, Berggren M, del Giorgio PA. 2013. Increases in terrestrially derived carbon stimulate organic carbon processing and $\mathrm{CO}_{2}$ emissions in boreal aquatic ecosystems. Nature Communications 4:2972.

Levin I, Kromer B, Hammer S. 2013. Atmospheric $\triangle{ }^{14} \mathrm{CO}_{2}$ trend in Western European background air from 2000 to 2012. Tellus B 65:20092.

Liu H. 2013. Thermal response of soil microbial respiration is positively associated with labile carbon content and soil microbial activity. Geoderma 193194:275-81.

MacDonald GM, Beukens RP, Kieser WE. 1991. Radiocarbon dating of limnic sediments: a comparative analysis and discussion. Ecology 72(3):1150-5.

Maguire C, Gibson C. 2005. Ecological change in Lough Erne: influence of catchment changes and species invasions. Freshwater Forum 24(1):38-58.

Maguire CM, Grey J. 2006. Determination of zooplankton dietary shift following a zebra mussel invasion, as indicated by stable isotope analysis. Freshwater Biology 51(7):1310-9.

Manning MP, Reid RC. 1977. CHO systems in the presence of an iron catalyst. Industrial and Engineering Chemistry Process Design and Development 16(3):358-61.

McCallister SL, del Giorgio PA. 2008. Direct measurement of the $\delta^{13} \mathrm{C}$ signature of carbon respired by bacteria in lakes: linkages to potential carbon sources, ecosystem baseline metabolism, and $\mathrm{CO}_{2}$ fluxes. Limnology and Oceanography 53(4):1204-16.

McConnaughey TA, Burdett J, Whelan JF, Paull CK. 1997. Carbon isotopes in biological carbonates: respiration and photosynthesis. Geochimica et Cosmochimica Acta 61(3):611-22.

McGeehin J, Burr GS, Jull AJT, Reines D, Gosse J, Davis PT, Muhs D, Southon JR. 2001. Stepped-combus- tion ${ }^{14} \mathrm{C}$ dating of sediment: a comparison with established techniques. Radiocarbon 43(2A):255-61.

Nara F, Imai A, Uchida M, Matsushige K, Komatsu K, Kawasaki N, Shibata Y, Amano K, Mikami H, Hanaishi R. 2010. High contribution of recalcitrant organic matter to DOC in a Japanese oligotrophic lake revealed by ${ }^{14} \mathrm{C}$ measurements. Radiocarbon 52(3):1078-83.

Neff J, Finlay J, Zimov S, Davydov S, Carrasco J, Schuur E, Davydova A. 2006. Seasonal changes in the age and structure of dissolved organic carbon in Siberian rivers and streams. Geophysical Research Letters 33:L23401, doi:10.1029/2006GL028222.

Pace ML, Cole JJ, Carpenter SR, Kitchell JF, Hodgson JR, Van De Bogert MC, Bade DL, Kritzberg ES, Bastviken D. 2004. Whole-lake carbon-13 additions reveal terrestrial support of aquatic food webs. $\mathrm{Na}$ ture 427(6971):240-3.

Polsenaere P, Savoye N, Etcheber H, Canton M, Poirier D, Bouillon S, Abril G. 2013. Export and degassing of terrestrial carbon through watercourses draining a temperate podzolized catchment. Aquatic Sciences 75(2):299-319.

Pulido-Villena E, Reche I, Morales-Baquero R. 2005. Food web reliance on allochthonous carbon in two high mountain lakes with contrasting catchments: a stable isotope approach. Canadian Journal of Fisheries and Aquatic Sciences 62(11):2640-8.

Rautio M, Vincent FW. 2007. Isotopic analysis of the sources of organic carbon for zooplankton in shallow subarctic and arctic waters. Ecography 30(1):77-87.

Rautio M, Mariash H, Forsström L. 2011. Seasonal shifts between autochthonous and allochthonous carbon contributions to zooplankton diets in a subarctic lake. Limnology and Oceanography 56(4):1513-24.

Raymond PA, Bauer JE, Caraco NF, Cole JJ, Longworth B, Petsch ST. 2004. Controls on the variability of organic matter and dissolved inorganic carbon ages in northeast US rivers. Marine Chemistry 92(14):353-66.

Reimer PJ, Brown TA, Reimer RW. 2004. Discussion: reporting and calibration of post-bomb ${ }^{14} \mathrm{C}$ data. $R a$ diocarbon 46(3):1299-304.

Roiha T, Tiirola M, Cazzanelli M, Rautio M. 2012. Carbon quantity defines productivity while its quality defines community composition of bacterioplankton in subarctic ponds. Aquatic Sciences 74(3):513-25.

Smyntek PM, Maberly SC, Grey J. 2012. Dissolved carbon dioxide concentration controls baseline stable carbon isotope signatures of a lake food web. Limnology and Oceanography 57(5):1292-302.

Stuiver M, Polach HA. 1977. Discussion: reporting of ${ }^{14} \mathrm{C}$ data. Radiocarbon 19(3):355-63.

Taipale S, Kankaala P, Jones RI. 2007. Contributions of different organic carbon sources to Daphnia in the pelagic foodweb of a small polyhumic lake: results from mesocosm $\mathrm{DI}^{13} \mathrm{C}$-additions. Ecosystems 10(5):757-72

Taipale S, Kankaala P, Tiirola M, Jones RI. 2008. Wholelake dissolved inorganic ${ }^{13} \mathrm{C}$ additions reveal season- 
al shifts in zooplankton diet. Ecology 89(2):463-74.

Taipale SJ, Brett MT, Pulkkinen K, Kainz MJ. 2012. The influence of bacteria-dominated diets on Daphnia magna somatic growth, reproduction, and lipid composition. FEMS Microbiology Ecology 82(1):50-62.

Torn M, Kleber M, Zavaleta E, Zhu B, Field C, Trumbore S. 2013. A dual isotope approach to isolate carbon pools of different turnover times. Biogeosciences Discussions 10(6):10,189-227.

Tranvik LJ, Downing JA, Cotner JB, Loiselle SA, Striegl RG, Ballatore TJ, Dillon P, Finlay K, Fortino K, Knoll LB. 2009. Lakes and reservoirs as regulators of carbon cycling and climate. Limnology and Oceanography 54(6):2298-314.

Tranvik LJ, Gudasz C, Koehler B, Kothawala D. 2013. Sequestration and loss of organic carbon in inland waters: from microscale to global scale. In: Xu J, Wu J, He Y, editors. Functions of Natural Organic Matter in Changing Environment. Dordrecht: Springer. p 349-51.

Trumbore S. 2000. Age of soil organic matter and soil respiration: radiocarbon constraints on belowground C dynamics. Ecological Applications 10(2):399-411.

Trumbore S, Schrumpf M. 2013. How can we best use radiocarbon data to support models of organic matter cycling in ecosystems? Geophysical Research Abstracts 15:EGU2013-3030.

Trumbore S, Vogel J, Southon J. 1989. AMS ${ }^{14} \mathrm{C}$ measurements of fractionated soil organic matter: an approach to deciphering the soil carbon cycle. $R a$ diocarbon 31(3):644-54.

van der Plicht J, Hogg A. 2006. A note on reporting radiocarbon. Quaternary Geochronology 1(4):237-40.

Vogel JS, Southon JR, Nelson DE, Brown TA. 1984. Performance of catalytically condensed carbon for use in accelerator mass spectrometry. Nuclear Instruments and Methods in Physics Research B 5(2):289-93.

Vuorenmaa J, Forsius M, Mannio J. 2006. Increasing trends of total organic carbon concentrations in small forest lakes in Finland from 1987 to 2003. Science of the Total Environment 365(1-3):47-65.

Wilkinson GM, Carpenter SR, Cole JJ, Pace ML, Yang C. 2013. Terrestrial support of pelagic consumers: patterns and variability revealed by a multilake study. Freshwater Biology 58(10):2037-49.

Winterdahl M, Futter M, Köhler S, Laudon H, Seibert J, Bishop K. 2011. Riparian soil temperature modification of the relationship between flow and dissolved organic carbon concentration in a boreal stream. $\mathrm{Wa}$ ter Resources Research 47(8):W08532.

Zhou Q, Gibson C, Foy R. 2000. Long-term changes of nitrogen and phosphorus loadings to a large lake in north-west Ireland. Water Research 34(3):922-6.

Zigah PK, Minor EC, Werne JP, McCallister SL. 2011. Radiocarbon and stable carbon isotopic insights into provenance and cycling of carbon in Lake Superior. Limnology and Oceanography 56(3):867-86. 